\title{
Anti-A33 Monoclonal Antibody KRN330
}

National Cancer Institute

\section{Source}

National Cancer Institute. Anti-A33 Monoclonal Antibody KRN330. NCI Thesaurus. Code C90583.

A recombinant fully human monoclonal antibody directed ag ainst the human A33 antigen, with potential immunomodulatory and antineoplastic activity. Anti-A33 monoclonal antibody KRN330 recognizes and binds to the human A33 antigen, which may stimulate the immune system to mount a cytotoxic T-lymphocyte $(C T L)$ response against A33-positive colorectal cancers. A33 antigen, a $43 \mathrm{kDa}$ transmembrane glycoprotein of the immunog lobulin superfamily, is highly and homogenously expressed in $95 \%$ of colorectal cancer cancers with only restricted expression in normal colonic mucosa and small bowel epithelia. 